\title{
Spiritualitás és személyes higiénia
}

\author{
Spiritualism and personal hygiene
}

\author{
Szerzők: $\quad$ Molnár András $s^{a, b} \bowtie$, Ipolyi Dóra ${ }^{c}$ \\ a: Pécsi Tudományegyetem, Regionális Politika és Gazdaságtan Doktori Iskola, Pécs, \\ b: Közép-Európai Egyetem, Közpolitikai Tanulmányok Központja, Budapest, \\ c: Pécsi Tudományegyetem, Pszichológia Doktori Iskola, Pécs
}

Beküldve: 2020.05.18.

doi: $\quad$ 10.24365/ef.v61i4.604

\begin{abstract}
Összefoglaló: Kétség kívüli, hogy a spiritualitás fontos szerepet tölt be az egyének életében a mentális egészségük szempontjából. De vajon milyen hatással van a vallás a fizikai egészségre, és milyen szerepet tölt be a személyes higiéniai magatartásban? Lehet-e szerepe a vallásnak a személyes higiéniára nevelésben, és ha igen, milyen jelentősége lehet a Covid-19 világjárvány tükrében? Tanulmányunkban áttekintjük a spiritualitás és a hit egészséggel kapcsolatos összefüggéseit, amelyek közül kiemeljük a személyes higiéniai szokásokat. Munkánk során a szakirodalmi eredmények és a különböző vallások írásai alapján bemutatjuk a spiritualitás és a higiéné kapcsolatát, ezzel felhívva a figyelmet a hit és az egészség kevéssé tárgyalt területére. A kézmosás rítusának középpontba állitásával szemléltetjük, hogy a különféle vallásokban milyen módon jelenik meg a Covid-19 világjárvány kapcsán ismét a figyelem középpontjába kerülő kézhigiéné kérdése, és mindennek milyen relevanciája lehet a népegészségügyi intervenciók szempontjából. Ennek megfelelően áttekintésünkben ismertetjük hat vallás: a keresztény, a zsidó, az iszlám, a hindu, a sinto és a bahái hit kézmosással kapcsolatos rituáléit. Mindezek áttekintését követően javaslatokat fogalmazunk meg, amelyek reflektálnak az állami és civil szereplők napjaink multikulturális terében végzett népegészségügyi törekvéseire. Úgy véljük, az egészségnevelésben aktív szerepet vállaló szakemberek számára különösen fontos a kultúraközi érzékenység, valamint klienseik vallási szokásainak ismerete, amely hozzájárulhat programjaik eredményességéhez. A higiénés üzenetek átadásába továbbá érdemes bevonni a vallási vezetőket, akik az érintett vallás rituáléin keresztül is felhívhatják a figyelmet a szeméIyes higiénia fontosságára.
\end{abstract}

Kulcsszavak: kézhigiéné; spiritualitás; kézmosás; személyes higiéné; Covid-19

Summary: Spiritualism serves an important role in the mental health of the individuals. But how does it affect physical health, and what role does it have in personal hygienic behaviour? Is it possible to give space to religions in awareness raising for personal hygiene? What possible role could they have in the light of the Covid-19 pandemic? This study reviews the linkage between spiritualism, faith and health, highlighting the customs related to personal hygiene. Based on literature and the religious texts we present the connection between spiritualism and hygiene to draw attention on this less represented research area. With the ritual of handwashing in the centre of this article, we illustrate that handwashing is an established custom in many religions, which has a potential in public health interventions and hygiene promotion activities. As main part of this study we review the ritual handwashing practices (ablution) of six religions, including Christianity, Judaism, Islam, Hindu, Shintoism and Bahá'i. After the review of these considerations, we phrase recommendations reflecting the contemporary multicultural environment of public health interventions. We argue that professionals involved in health promotion should establish an intercultural awareness, 
including knowledge on religious customs of beneficiaries, which might have a positive effect on the success of their programmes. We also suggest to involve religious leaders in hygiene promotion activities as they might be able to utilize religious rituals as examples for good hygienic behaviour.

Keywords: hand hygiene; spiritualism; washing hands; personal hygiene; Covid-19

\section{BEVEZETÉS}

Ahogy Bagdy Emőke (2014) is összefoglalja munkájában, a spiritualitásnak, a transzcendenssel való kapcsolatnak komoly szerepe van az egyének és közösségek egészségtudatának fejlődésében. A spiritualitást a mentális egészség egyik összetevőjének tartjuk, a vallásokra pedig, mint ritualizált gyakorlatot képviselő közösségi spirituális rendszerekre tekintünk. A spiritualitás olyan érzésekre és tapasztalatokra utal, amelyek az élet értelmével és az élet céljaival, azaz egyfajta emberi útkereséssel állnak összefüggésben. A gyakorolt spiritualitás, valamint az egészség és életminőség között pozitív összefüggéseket állapítottak meg, ezért a spiritualitás a személyiség egészségvédő faktorjaként nevezhetjük meg. ${ }^{1,2}$

De vajon a mentális egészség mellett hogyan hat a vallásgyakorlás vagy a transzcendenssel ápolt kapcsolat a fizikai egészségre?

Az egészség és a vallásosság kapcsolata igen kiterjedt irodalommal rendelkezik. A területet vizsgáló kutatások jelentős része a vallás és a hit mentális egészségre gyakorolt hatásával, vagy a pszichoneuroimmunológiai aspektussal foglalkozik. ${ }^{3,4}$

A vallásosság és a vallásgyakorlás mentális egészségre gyakorolt hatását számos kutatás igazolta már, ezek az érintettek élettel való nagyobb fokú megelégedettségéről, pozitívabb érzelmekről számoltak be. Az eredmények szerint a hívők kevésbé hajlamosak a depresszióra és a szuicid gondolatokra, valamint jobban ellenállnak a káros szenvedélyek kísértésének is. A vallás, illetve a spiritualitás a megküzdési stratégiák mellett a személyiségfejlődésre is hatással van, hiszen összefüggésbe hozható nagyobb nyitottsággal vagy lelkiismeretesebb életvitellel is. ${ }^{5}$

A pszichoneuroimmunológia területe azzal foglalkozik, hogy a különböző társas és pszichológiai tényezők hogyan befolyásolják az emberi neuroendokrin folyamatokat és az immunrendszer múködését. A vallás mentális egészséghez fűződő kapcsolatát viszonylag kevés figyelem övezte a XX. század második feléig, és még kevesebb tanulmány foglalkozott a hit fizikai egészségre gyakorolt hatásával. A stressz az emberi testen belül számos biológiai folyamatot vált ki, amelyek megboríthatják testünk egyensúlyát, a homeosztázist, ezért különösen fontos kérdés, hogyan tudunk alkalmazkodni a minket ért hatásokhoz. A hit és a vallások gyakorlása a stresszel való megbirkózás eszköztárának fontos elemét képezi sokak számára. A kutatások azt mutatják, hogy a hit hozzájárul a pozitív érzelmek kialakulásához, az élettel való elégedettséghez, a jólléthez és a boldogsághoz, amely fontos faktor a különböző betegségek megelőzése szempontjából. A vallás gyakorlása emellett egyfajta védőhálót is nyújthat az embernek: a rituális események látogatása és a közösséghez való tartozás magasabb szocializációhoz vezethet, amely különösen fontos az öregedés során fellépő egészség-romlással való megbirkózás során. A hit a betegségekkel való megküzdésben is fontos: a Koenig (2002) által bemutatott kutatások vallástól függetlenül megállapították, hogy a halálozás aránya alacsonyabb az egyes betegségekben vagy kritikus állapotban lévő hívő betegeknél, mint vallást nem gyakorló társaiknál). ${ }^{3}$

A hit és a vallás gyakorlása tehát vélhetően összefüggésben áll a fizikai egészséggel, ez a kapcsolat pedig többszintű és többrétegű. Míg a fenti tanulmányok a hit mentális egészségen keresztül érvényesülő hatásával foglalkoznak, dolgozatunkban fel kívánjuk hívni a figyelmet a vallások rítusaiban megjelenő higiénés és egészségnevelési gyakorlatokra, ezzel kapcsolódva a Covid-19 világjárványhoz füződő, kézmosást érintő diskurzushoz.

\section{MÓDSZEREK}

Összefoglaló munkánk kvalitatív vizsgálat, melynek során összegyújtöttük és megvizsgáltuk az érintett vallások írásos szövegeit és a hozzájuk füződő szakirodalmat, valamint a releváns hazai és nemzetközi 
egészségügyi közleményeket. A forrásmunkákat a Közép-Európai Egyetem könyvtárában, valamint a Google Scholar és a ScienceDirect keresőjével leltük fel, amelyet az Akadémiai Kiadó folyóiratkeresőjében történő kereséssel egészítettünk ki. Az elsődleges keresőszavak a vallás, kézmosás, higiénia angol nyelvű megfelelői (religion, hand washing, ablution, hygiene) voltak. Az összegyüjtött információkat rendszerezést követően szakirodalmi elemzést végeztünk, a különböző megállapításokat vallásonként rendszereztük és az eredmények fejezetben kifejtett módon értelmeztük.

\section{EREDMÉNYEK}

Munkánk során 23 forrásmunka, valamint a vizsgált vallások szöveges anyagainak feldolgozását végeztük el. A kereszténység, a zsidó hit, a hindu, a buddhista, a sintoista valamint a bahái vallás és az iszlám esetében vizsgáltuk meg a kézhigiénés szokásokat. Megállapítható, hogy a buddhizmuson kívül mindegyik vizsgált vallás tartalmaz valamilyen utalást rituális kézmosásra, és ezek figyelembevétele segítheti a népegészségügyi intervenciók sikerességét.

\section{Kézhigiéné hat vallás rítusaiban}

A vallás és a személyes higiéné kapcsolata különösen fontosnak bizonyulhat népegészségügyi intézkedések és humanitárius múveletek során. Az egyének és közösségek kulturális háttere több szinten befolyásolja az egészséget és a jóllétet. ${ }^{6,7,8} \mathrm{~A}$ vallási gyakorlatok és hatások figyelmen kívül hagyása sajnos több népegészségügyi intervenció kudarcához, eredménytelenségéhez vezetett. Az elmúlt évtizedekben bizonyossá vált, hogy globalizált világunkban nem elegendő homogén kulturális környezetet alapul venni a népegészségügyi intézkedések tervezésekor, azok eredményessége érdekében figyelembe kell venni az adott területre érkező külföldi látogatók és a bevándorló, esetleg diaszpóra (szórvány) lakosság kulturális és vallási sajátosságait is. ${ }^{9}$

A közelmúltban a koronavírussal kapcsolatban a személyes higiéniai gyakorlatok közül a kézmosás került a figyelem középpontjába. Sokkoló tény, hogy több mint másfél évszázaddal John Snow és Semmelweis Ignác halálát követően a világon élő emberek mintegy 19\%-a mos csak megfelelően kezet széklettel való érintkezést követően. ${ }^{10}$ A személyes higiéniával kapcsolatos diskurzus aktualitását mutatja, hogy azokban az országokban, amelyekben a kézmosásra vonatkozó internetes keresések száma magasabb volt, tehát az emberek fogékonyabbak voltak a helyes kézmosás módszertana iránt, a Covid-19 terjedése lassabbnak mutatkozott. ${ }^{11}$

A kézmosás aktusa különféle módon jelenik meg a különböző vallásokban, és a vallási hiedelmek többféle módon befolyásolhatják a kézmosási gyakorlatokat. ${ }^{12}$ Számos vallásban rituális szerepe van a kézmosásnak, amely a napi rituálék gyakoriságától függően komoly hatással van az egyének személyes higiéniai magatartására.

A személyes higiénia az Ószövetségben Mózes II. könyvében kap kiemelt szerepet (2Móz 30, 18-20), amely szerint az Úr úgy határoz, a kijelentés sátra és az oltár közé rézből készült mosdómedencét kell helyezni, hogy az Isten színe elé térők abban mossák meg kezüket és lábukat, mielőtt az oltárhoz járulnak. Mózes III. könyvében a menstruációval kapcsolatban is megfogalmaz higiéniai szabályokat: például aki olyan tárgyhoz ért, amely az asszony vérével szennyezett lehet, meg kell mossa ruháit, és meg kell mosakodnia vízben. (3Móz 15, 19-28). A kereszténység és a Biblia azonban más szakaszaiban nem követel meg konkrét személyes higiéniát érintő gyakorlatot - Jézus példája inkább spirituális értelemben vett lelki tisztaságra utal, mintsem fizikai higiéniára. Mindez persze nem jelenti azt, hogy a keresztény kultúrkörben ne lenne fontos a személyes higiénia és a fizikai tisztaság. ${ }^{3} \mathrm{~A}$ higiénia és a kereszténység kapcsolatával összefüggésben érdemes említést tenni arról, hogy sok esetben a megbetegedést valamely elkövetett bún következtében kialakuló büntetésként értékelik a közösségek. A koreai protestáns közösségekben ennek megfelelően a rendszeres rituális tisztálkodás egyszerre szolgált a higiéniai és spirituális megtisztulás eszközéül. Kim (2008) koreai esettanulmánya kiváló példája annak, amikor a vallási, spirituális rituálék népegészségügyi célt is szolgálnak. A protestáns missziók Koreába történő érkezése ugyanis párhuzamosan zajlott a nyugati orvoslás megtelepedésével a XIX. század végén, így a higiéné és a vallás keveredése általánosan elfogadottá válhatott. Ehhez az amerikai misszionáriusok a bún és a 
kórokozók közötti vélt kapcsolatot használták fel, amelyet megkönnyített, hogy mind a vallási értelemben vett bűn (illetve a bűnös gondolatok), mind a kórokozók a szabad szem számára láthatatlanok voltak. ${ }^{13}$

A zsidó vallásban a hit helyhez kötöttségének megszűnésével a kézmosás mindennapos rituálévá vált, amely alapja Mózes II. könyvének hivatkozott szakasza. A rituálé az étkezések előtt megvalósuló netilat yadayimban (kézmosás rituális gyakorlata) testesül meg, és több jiddis írásban is kodifikálásra került. ${ }^{14}$ Mózes a vándorlás ellenére eredményesen alkalmazott higiéniai előirásokat népe körében, amellyel vélhetően hozzájárult ahhoz, hogy járványok és megbetegedések nem alakultak ki a vándorlás során. ${ }^{15}$ A Mózes könyveiben foglalt törvények közül számos mai napig releváns, és helytállnak a betegségek megelőzésében a modern orvostudomány követelményei között is. ${ }^{16,17}$

A hindu vallás rituális kézmosását a Bhagavad-gíta soraiban fedezhetjük fel. A négy lépésből álló rituális megtisztulás során először a kezet mossák meg (Argyam Samarpayami), majd a láb mosása következik (Paadhyam Samarpayami), ezt követően egy korty vízzel a torkot tisztítják (Aachamaniyam Samarpayami), végezetül a fogakat és a nyelvet tisztítják meg. ${ }^{18}$

Hindu területeken a hétköznapi kéztisztításra emellett elterjedt módszer, hogy a kézfejet hamuval vagy sárral dörzsölik be, majd leöblítik vízzel. A hagyományos szappan használata, mivel az gyakran állati zsiradékból készül, nem megengedett a hindu vallásgyakorlók számára. Egy bangladesi laboratóriumi vizsgálat ugyanakkor megállapította, hogy a hamuval és sárral történő kéztisztítás is éppoly hatékony lehet, mint a szappanos kézmosás. ${ }^{19}$

Az Iszlám és a higiénia kapcsolatával számos írás foglalkozik. A Korán ugyanis több, személyes higiéniához kapcsolódó gyakorlatot ír elő, köztük a Wudu és Ghuszl rituáléját. ${ }^{20} \mathrm{Az}$ ima előtti rituális bemosakodás, a Wudu gyakorlata hasonlóan a hindu, és a bahái rituáléhoz nem csupán a kéz mosását foglalja magában. A Wudu során az elhatározást és a biszmillah szó kiejtését követően először a kezeket mossák meg csuklóig, amelyet háromszor megismételnek. Ezt követően a szájüreg háromszori kiöblítése, majd az orrüreg háromszori öblítése következik. A Wudu során az arcot homloktól lefelé, két kézzel, egészen az állig és fülig kell megmosni, szintén három alkalommal. Ezt a karok három alkalommal történő mosása követi, előbb a jobb, majd a bal kart könyékig megtisztítva. A haj átdörzsölése, a fülkagyló belsejének és a fül mögötti terület megtisztításának elvégzését követően pedig a két láb bokáig történő, háromszori mosásával zárul a rituálé. ${ }^{21} \mathrm{~A}$ teljes mosakodást, a Ghuszl-t számos esetben kötelező elvégezni, például bárminemű nemi érintkezést követően teljes testes mosdás szükséges. ${ }^{20} \mathrm{~A}$ Korán azokról az esetekról is rendelkezik, amikor nem áll rendelkezésre tiszta víz. A Tajammum a homokkal történő mosakodás rituáléja, ezt a legmagasabb és legtisztább helyen megtalálható száraz homokkal lehet csak elvégezni, szokványos, nedves talajokkal nem. ${ }^{22} \mathrm{~A}$ Tajammum megfelelően elvégezve helyettesítheti a Wudu és a Ghuszl rituáléját is. ${ }^{21}$

A Covid-19 világjárvány fényében fontos megemlíteni az alkoholos kézfertőtlenítőkkel szembeni ellenállást, amelyet a modern iszlám államokban a tudomány segített csillapítani. Bebizonyítva ugyanis, hogy az alkohol a bőrön keresztüli felszívódása elhanyagolható mértékü, az alkohol tartalmú kézfertőtlenítő szereket a modern iszlám államokban széleskörüen alkalmazzák. .3,24 $^{23}$

A sinto szentélyek felkeresése előtt szintén kötelező a rituális megtisztulás: a Temizu során a kezek és a száj folyóvízzel való mosása történik meg. ${ }^{25} \mathrm{~A}$ szumó birkózók a ringbe lépés előtt is megmossák kezeiket és szájukat, pont úgy, mint egy szent hely felkeresése előtt. ${ }^{26}$

A bahái vallásban a kötelező imádságokat megelőzően szükséges a kezek és az arc rituális megmosása. ${ }^{27}$ Ezzel szemben a Buddhizmus írásaiban nem találunk a kézmosásra vonatkozó útmutatást vagy kodifikált rituálét. ${ }^{3}$

\section{KONKLÚZIÓ ÉS JAVASLATOK}

Tanulmányunkban ismertetjük a spiritualitás és az egészség alapvető kapcsolatát, és megvizsgáltuk, hogy hat jelentős vallás hogyan alkalmazza a kézmosást a rituális megtisztulás részeként. Globalizálódott világunkban különösen fontosnak tartjuk, hogy a népegészségügyi és humanitárius szakemberek interkulturális nézőpontból is megvizsgálják a különböző programokat és intézkedéseket azok bevezetése előtt. Jelen tanulmány ehhez kíván hozzájárulni 
azzal, hogy bemutatja, milyen jelentőséggel bír a kézmosás a különböző vallások gyakorlása során. Fontos azonban azt is kijelenteni, hogy a rituális kézmosás nem feltétlen hatékony a kórokozók elleni küzdelem során: ahogy ismertetésre került, a rituálék tiszta vízzel zajlanak, detergensek, mint a szappan használata nem képezi a vallási gyakorlatok részét. A hivatkozott szakirodalmak viszont egyértelműen amellett érvelnek, hogy a vallási gyakorlatok felhasználhatóak a megfelelő egyéni higiénia kialakításában és a betegségek megelőzésében. ${ }^{3,10,13,14}$

A fentieket figyelembe véve javaslatként fogalmazhatjuk meg a vallási vezetők számára, hogy az illetékes népegészségügyi hatóságok ajánlásaira tekintettel hívják fel híveik figyelmét a megfelelő személyes higiéniára, amelyre példaként használják fel a vallásuk szent írásaiban megtalálható rituális útmutatásokat. A rituális tisztálkodási gyakorlatok fontos szereppel bírtak az évszázadok során a különböző betegségek megelőzésében, azonban a történelmi időkből származó gyakorlatokat napjainkban szükséges kiegészíteni a korszerű előírások betartásával. Ezzel párhuzamosan a multikulturális környezetben dolgozó népegészségügyi, szociális és humanitárius szakemberek számára kiemelt fontosságú, hogy megismerjék célcsoportjuk, az érintett lakosság kulturális és vallási szokásait.

\section{HIVATKOZÁSOK}

\footnotetext{
${ }^{1}$ Bagdy E. (2014). Mentális egészség és spiritualitás. Magyar Pszichológiai Szemle, 69(4):643-663. doi:10.1556/MPSzle.69.2014.4.1

${ }^{2}$ Brinkenhoff, M.B.,Jacob, J.C. (1987). Quasi-religious meaning systems, official religion, and quality of life in an alternative lifestyle: A survey from the back-to-the-land movement. J Sci Study Relig. 26, 63-80. doi:10.2307/1385841

${ }^{3}$ Allegranzi B, Memish ZA, Donaldson L, Pittet D. (2009). Religion and culture: Potential undercurrents influencing hand hygiene promotion in health care. Am J Infect Control, 37(1):28-34. doi:10.1016/j.ajic.2008.01.014

${ }^{4}$ Koenig HG. (2002). The Connection between Psychoneuroimmunology and Religion. In: Koenig HG, Cohen HJ, eds. The Link between Religion and Health : Psychoneuroimmunology and the Faith Factor. Oxford University Press, 11-30.

${ }^{5}$ Pikó B, Kovács E, Kriston P. (2011). Spiritualitás - vallás - egészség. Fiatalok mentális egészsége a spirituális jóllét mutatóinak tükrében. Mentálhigiéné és Pszichoszomatika, 12(3):261-276. doi:10.1556/Mental.12.2011.3.4

${ }^{6}$ Vitrai, J. (2017) Hogyan befolyásolja a kultúra az egészséget és a jóllétet? I. rész: Az egészség kulturális beágyazottsága. Egészségfejlesztés, LVIII(2), 38-41. doi:10.24365/ef.v58i2.158

${ }^{7}$ Nagy, B. (2017) Hogyan befolyásolja a kultúra az egészséget? II. rész: Táplálkozás, kultúra és egészség. Egészségfejlesztés, LVIII(2), 42-46. doi: 10.24365/ef.v58i2.159

${ }^{8}$ Csizmadia, P. (2017) Hogyan befolyásolja a kultúra az egészséget és a jóllétet? III. rész: Környezet, kultúra és egészség. Egészségfejlesztés, LVIII(2), 47-50. doi:10.24365/ef.v58i2.160

${ }^{9}$ (WHO). World Health Organization Guidelines on Hand Hygiene in Health Care. (2009) http://whqlibdoc.who.int/publications/2009/9789241597906 eng.pdf. /Letöltve: 2020.04.12./

${ }^{10}$ Freeman MC, Stocks ME, Cumming O, et al. (2014). Systematic review: Hygiene and health: systematic review of handwashing practices worldwide and update of health effects. Trop Med Int Heal, 19(8):906-916.

doi:10.1111/tmi.12339

${ }^{11}$ Lin YH, Liu CH, Chiu YC.(2020). Google searches for the keywords of "wash hands" predict the speed of national spread of COVID-19 outbreak among 21 countries. Brain Behav Immun, 4,0-1. doi:10.1016/j.bbi.2020.04.020

12 Inamulhaq M, S.A A, Haq S. (2012). Role of hand washing in prevention of communicable diseases and practices adopted in private clinics. Can J App/ Sci.,2(1):196-201.

${ }^{13}$ Kim SK. (2008). An antiseptic religion: Discovering a hybridity on the flux of hygiene and christianity. J Relig Health, 47(2):253-262. doi:10.1007/s10943-008-9172-3

${ }^{14}$ Zeffren N, Chien T, Stern R. (2017). Public Health Measures Derived from the Jewish Tradition : II . Washing and Cleaning. Hektoen Int J, 9(1).

${ }^{15}$ Subhaktha PK, Prasad P V., Narayana A. (2007). Precepts of community health and hygiene from the Holy Bible. Bull Indian Inst Hist Med Hyderabad, 37(2):107-116.

${ }^{16}$ Sun JF. Medical implication in the Bible and its relevance to modern medicine. J Integr Med. 2013;11(6):416-421. doi:10.3736/jintegrmed2013052
} 
${ }^{17}$ Mazokopakis EE. (2019). The prevention of cholera in the Bible. Vaccine, 37(35):4850. doi:10.1016/j.vaccine.2019.03.042

${ }^{18}$ Trust J.(2020). Essence of Bhagavad Gita. Pustaka Digital Media Pvt. Ltd;

${ }^{19}$ Hoque BA, Briend A. (1991). A comparison of local handwashing agents in Bangladesh. J Trop Med Hyg, 94(1):61-64.

${ }^{20}$ Newby GD. (2002). A Concise Encyclopedia of Islam. Oxford: Oneworld Publications.

${ }^{21}$ Shubail ME, ed. (2006). Az Imádkozás. Magyarországi Muszlimok Egyháza.

${ }^{22}$ Mihalffy AR, ed. Al- Quran. (2017).Korán : Angol És Magyar Fordítás És Magyarázatok.; https://mek.oszk.hu/17000/17082/pdf/. /Letöltve: 2020.04.13./

${ }^{23}$ Wai Khuan N, Shaban RZ, van de Mortel T. (2020). Hand hygiene beliefs and behaviours about alcohol-based hand rub use: Questionnaire development, piloting and validation. Infect Dis Heal, 25(1):43-49. doi:10.1016/j.idh.2019.10.001

${ }^{24}$ Wai Khuan N, Shaban RZ, van de Mortel T. (2018). The influence of religious and cultural beliefs on hand hygiene behaviour in the United Arab Emirates. Infect Dis Heal, 23(4):225-236. doi:10.1016/j.idh.2018.07.004

${ }^{25}$ Bocking B. (1997). A Popular Dictionary of Shinto. Taylor \& Francis;

${ }^{26}$ Hartz PR. Shinto. (2009). 3rd ed. New York: Chelsea House.

27 Smith P. (2000). A Concise Encyclopedia of the Bahá'í Faith. Oxford: Oneworld Publications, 21. 